\title{
Dissociation of corpus luteum, endometrium and blastocyst in human implantation research
}

\author{
H. M. Beier, W. Elger*, C. Hegele-Hartung, U. Mootz and K. Beier-Hellwig \\ Department of Anatomy and Reproductive Biology, Medical Faculty, RWTH Aachen, Germany
}

\begin{abstract}
Summary. We describe a well-established approach for studying the parameters and mechanisms of synchronization or desynchronization between the maternal and embryonic systems before implantation. It is useful for inducing 'delayed secretion' of the endometrium by different endocrine interventions, which dissociate the endometrial transformation from its control by the corpus luteum. The technique has been achieved by means of direct progesterone antagonists which competitively bind to the progesterone receptor and, in turn, inhibit the physiological effects of progesterone. During the luteal phase, secretory protein patterns indicate the receptive stage of the endometrium. Evidence is presented to show that these patterns, analysed by electrophoresis and densitometry, define the time at which an embryo transfer is promising for implantation and establishment of pregnancy.
\end{abstract}

Ke!words: uterine proteins; corpus luteum, blastocyst; implantation; progesterone antagonists; human

\section{Synchrony and dissociation in early pregnancy}

Mammals have developed remarkable physiological, morphological and endocrinological diversity to accomplish reproduction in each species, but have a fascinating, common feature known as the 'synchrony' between the mother and the early embryo. This synchrony between the reproductive state of the genital tract of the mother and the developmental stage of the embryo encompasses interactions and factors beyond the mere dimension of time, as described by the original Greek term synchrony. In addition to the correct timing, there are numerous, specific demands concerning cleavage stages and sites of blastocyst arrival, environmental physiological conditions, embryonic cell differentiation, and the molecular signals released by the mother and the embryo. With this information at hand, one can easily understand why normal implantation and, in turn, normal pregnancy can only occur if synchronization has been established between the maternal reproductive tract and embryonic development during the period between ovulation and the midluteal phase. From the embryonic point of view, synchronization includes correct timing and an appropriate topology; any deviation results in defined 'desynchronization'.

A well-established experimental approach for studying synchronization during early mammalian reproduction consists of inducing controlled dissociation of the normal synchrony between mother and embryo. Embryo transfer experiments have revealed a great deal concerning the requirements for synchronization: preimplantation embryos of any developmental stage can be transferred into selected recipient oviducts or uteri at various stages in early pregnancy.

Our recent endocrinological experiments, which were designed to examine more-detailed dissociations of parts of the maternal reproductive system, have revealed a new aspect of synchrony. Postcoital applications of oestrogens and postovulatory progesterone-antagonist treatments achieve

*Address: Schering Institute of Pharmacology, Department of Experimental Gynecology and Fertility Research, Berlin, Germany. 


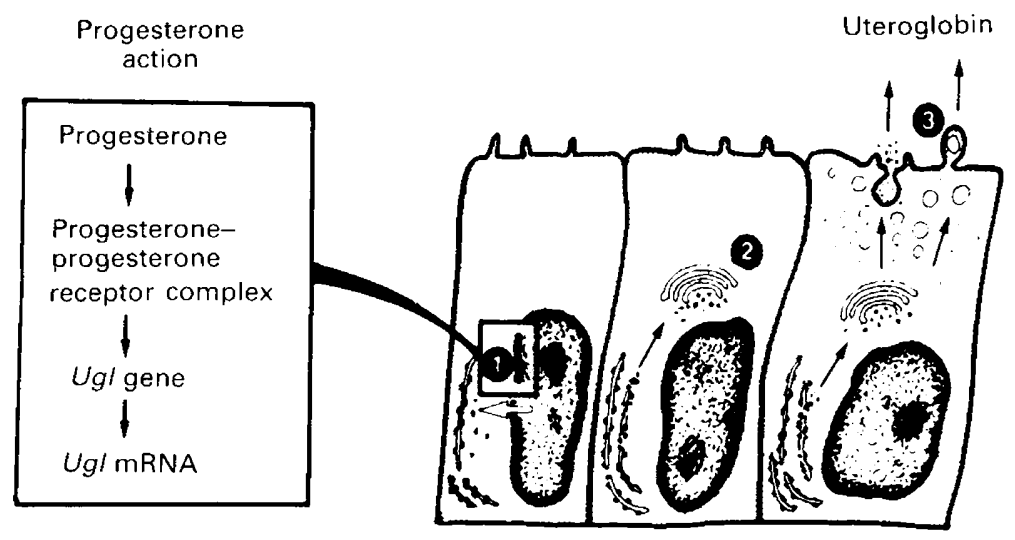

Fig. 1. Pathway of uteroglobin synthesis and release. (1) Uteroglobin is initially synthesized as pre-uteroglobin at the ribosomes of the endoplasmic reticulum in endometrial epithelial cells (cf. Loosfelt et al., 1981; Suske et al., 1983). It has been difficult to localize uteroglobin immunocytochemically at this site using postembedding procedures (Aumüller et al., 1985, HegeleHartung \& Beier, 1985), but, using a preembedding technique, Shroyer et al. (1987) were able to demonstrate uteroglobin immunocytochemically within the endoplasmic reticulum. (2) Uteroglobin is easily localized within the Golgi complex, where it is processed and packed into small membrane-bound vesicles. (3) Secretory uteroglobin is found beneath the apical plasma membrane where it is available for release into the uterine lumen.

controlled dissociation, affecting only the synchrony between corpora lutea and the endometrium. By combining an endocrinologically dissociated maternal system with transferred embryos of untreated animals, we are able to permutate at will the corpus luteum, the endometrium and the embryo, i.e. all three major components of an establishing pregnancy can now be varied under controlled conditions for more-detailed investigation of the mechanisms involved in embryo implantation and the establishment of pregnancy.

\section{Macromolecular composition of the uterine environment of blastocysts}

The uterine secretion milieu serves various functions. It enables the spermatozoa to ascend to the site of fertilization within the oviduct; it provides adequate nutrition for the embryo during its various developmental stages between its arrival in the uterine lumen until it has achieved implantation and maintains an appropriate environment for the physical and biochemical integrity of the blastocyst structures (osmolarity is an important aspect); and it meets specific immunological requirements, which becomes increasingly important during the preimplantation phase, as the individual genes of the blastocyst are expressed as differentiation progresses. The quality of the macromolecular uterine components is, in general, permissive. The uterine environment, which exists to guarantee a milieu offering optimum developmental conditions for the blastocyst, has, however, no inductive effect upon the conceptus by directly influencing its developmental capacity or genetic potency. But, although the embryonic genes act independently, embryonic development, in terms of nutrition and growth, is dependent on the uterine environment. For reproductive performance, the quality of the uterine secretion milieu is reflected in the fertility of the mother.

The proteins in luminal uterine secretions are derived from blood plasma proteins and from endometrial secretory products. Specific endometrial proteins synthesized by epithelial gland cells have been described, isolated and analytically characterized (amino acid composition and sequence) in only a few mammalian species. Particular attention has been concentrated on uteroglobin (Beier, 1966, 1967), a progesterone-dependent secretory protein in the rabbit uterus. Uteroglobin is the predominant fraction of endometrial secretion and is found in uterine glandular and luminal epithelium cells during certain preimplantation stages (for a detailed review, see Beier, 


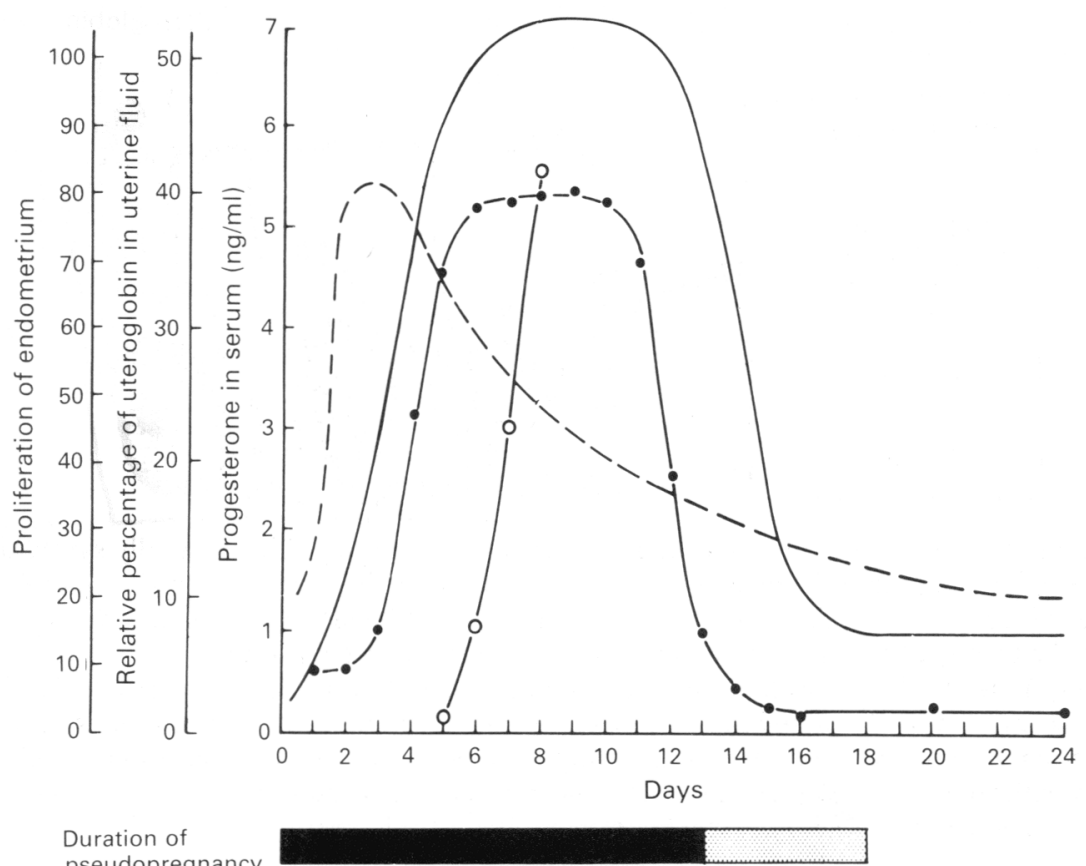

Fig. 2. Parameters which define 'pseudopregnancy' in rabbits. Duration of pseudopregnancy is usually calculated as up to 18 days after initiation by triggering ovulation either by natural mating or by injection with human chorionic gonadotrophin (hCG). The lifespan of the corpus luteum during pseudopregnancy is up to Day 12 or 13 after hCG injection. There are three important parameters: proliferation index of the endometrial tissue (-- ), relative percentage of uteroglobin in flushed uterine secretion $(\bullet)$ and the progesterone values in peripheral blood serum $(-)$ in $\mathrm{ng} / \mathrm{ml}$. In addition, there is the delayed uteroglobin secretion demonstrated as it appears after preimplantational antiprogesterone treatment (Progesterone antagonist Lilopristone, ZK 98.734). The relative percentage of uteroglobin is shown from Day 5 to Day $8(O)$, it clearly demonstrates a delay of $\sim 72 \mathrm{~h}$ of uteroglobin release after progesterone antagonist treatment compared with the controls which had no treatment.

1982). The intracellular location of uteroglobin within its synthesizing cells was first demonstrated by electron microscopy and immunohistological methods in our laboratory (Hegele-Hartung \& Beier, 1985). These studies demonstrate that uteroglobin is primarily synthesized by the basal gland cells (epithelial cells) of the endometrium. It can be detected first in the Golgi complex and later in the secretory vesicles, which accumulate beneath the apical cell membrane, whence it is finally released into the glandular and uterine lumen (see Fig. 1). The expression of the uteroglobin gene demonstrated by in-situ hybridization with cloned uteroglobin cDNA (Warembourg et al., 1986) confirmed our findings. All these steps, gene expression, intracellular processing and the release of uteroglobin, are controlled by progesterone (Loosfelt et al., 1981; Beier, 1982; Suske et al., 1983) (see progesterone concentration in rabbits after induction of ovulation, Fig. 2).

Uterine protein content usually increases during preimplantation in most mammalian species investigated. High protein concentrations in the uterine fluids during the later stages of preimplantation are, in part, caused by a decreasing water content and, in turn, an increasing viscosity due to the influence of progesterone. Several species produce specific uterine proteins that are not found elsewhere, i.e. in other organs or body fluids. Among these species are cows (Roberts \& Parker, 1974; Laster, 1977; Dixon \& Gibbons, 1979), pigs (Squire et al., 1972; Roberts \& Bazer, 1980; Bazer \& Roberts, 1983), sheep (Roberts et al., 1976) and horses (Zavy et al., 1982). In experiments with laboratory animals, de-novo synthesis was demonstrated after radioactively labelled precursors 


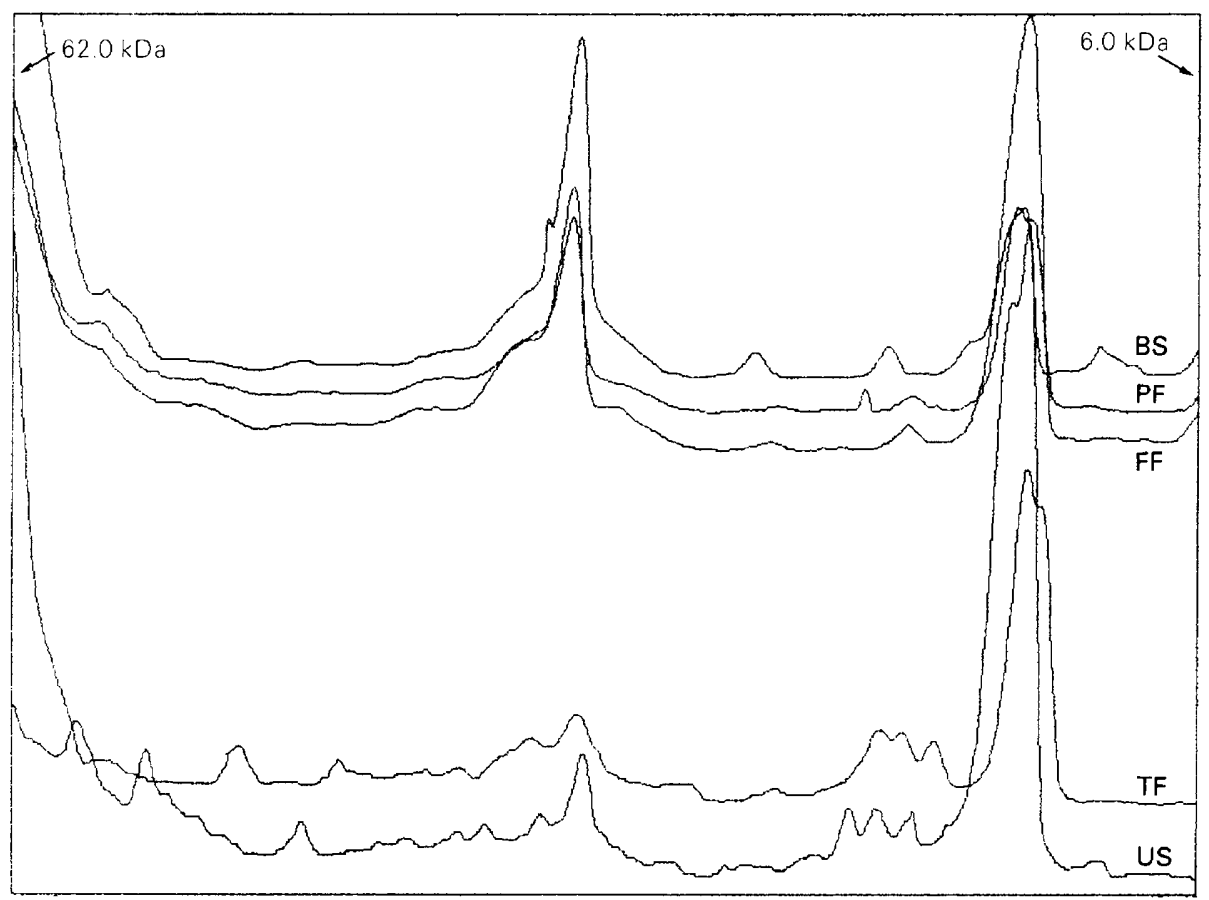

Fig. 3. Densitometric tracing of SDS-PAGE samples of blood serum (BS), peritoneal fluid (PF), follicular fluid (FF), tubal fluid (TF) and uterine secretion (US), all involved in female reproduction. The tracings demonstrate that there are similarities between $\mathrm{BS}, \mathrm{PF}$ and FF and between TF and US. Laser-Densitometer: Pharmacia/LKB (Freiburg, Germany) Ultro-ScanXL, He-Ne-Laser $633 \cdot 0 \mathrm{~nm}$. SDS-PAGE: 8.3-16.0\% PAA-Gradient, Coomassie Blue-R-250 staining. The 5 samples were obtained from different patients, but all from the beginning of the luteal phase, from comparable stages of the menstrual cycle and without endocrine disorders.

were incorporated into the uterine secretion proteins (Pratt, 1977; Surani, 1976; Fishel, 1980; Mulholland \& Villee, 1984).

Characteristic protein pattern changes occur during short periods in the preimplantation phase. Such changes have been described in rodents (rats, Surani, 1976; and mice, Aitken, 1977) and may appear among the macromolecular fractions of electrophoretically resolved patterns. Entire 'families' or groups of electrophoretic bands may differ characteristically at different progestational stages (Surani, 1976). Numerous studies have shown that the pattern of staining intensity of these protein changes in electrophoresis indicate that most changes are quantitative rather than qualitative. Traces of rat and mouse macromolecular fraction proteins were eventually found even during various nongestational stages (Aitken, 1982).

Uterine secretion patterns, extensively studied in rabbits are reliable markers for the course of normal and pathologically altered preimplantation periods. This is important because morphological alterations are far less useful in identifying variations from the norm. When applying both methods simultaneously, one expects the most detailed information and interpretations from the biochemical data, but morphological information (preferably obtained by electron microscope examination) is also valuable, as it may indicate the location of events. During endocrinological studies on uterus protein regulation, we studied endometrial ultrastructure. In detail, the epithelial layer of endometrium cells is remarkably dynamic. The cells which contribute to the uterine secretion, and particularly to the composition of the protein patterns, react promptly to stimulation by steroid combinations or synthetic steroid compounds (Beier \& Mootz, 1979; Beier et al., 1979; Beier et al., 1980). Even after a complete loss of the epithelial cells, repairs start as soon as 


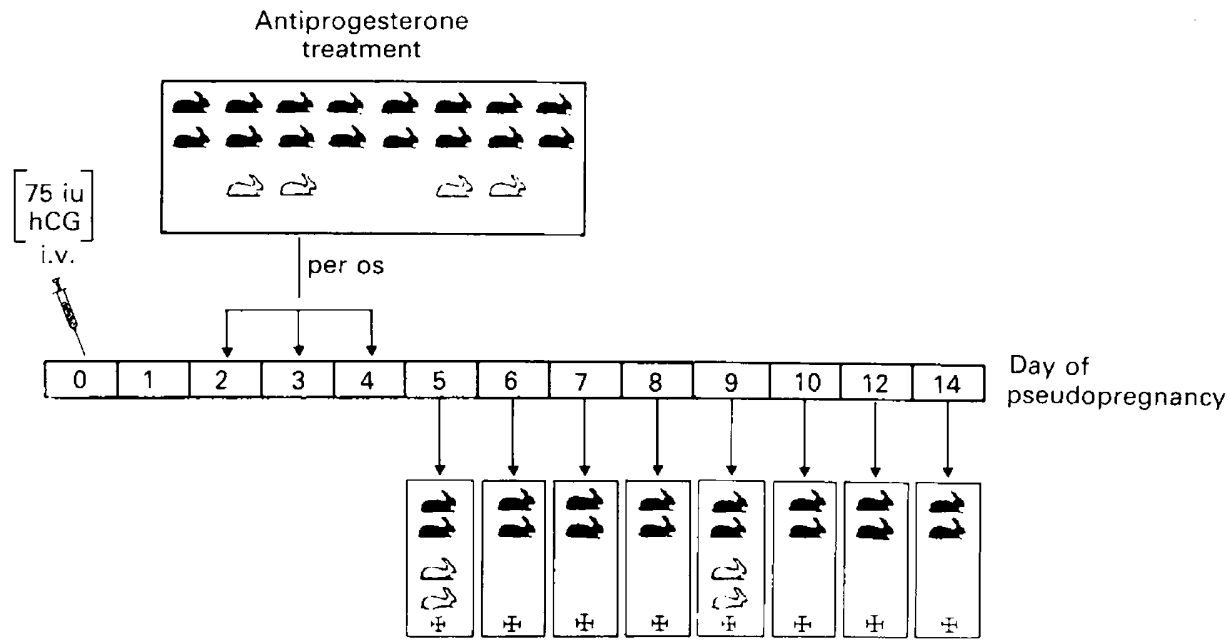

\footnotetext{
$\Rightarrow 20 \mathrm{mg}$ antiprogesterone/kg body wt per os per day

$\Leftrightarrow 5 \mathrm{ml}$ Myrj oil vehicle per os per day (control)
}

Fig. 4. Experimental schedule for the initiation and analysis of the 'delayed secretion' phenomenon in the rabbit uterus. Delayed secretion was first detected by Beier et al. (1971) using postcoital oestradiol-17 $\beta$ injections (Day 0 and Day 1 p.c.). A similar phenomenon has been achieved by postovulatory and preimplantational application of potent antagonists to progesterone; we used Lilopristone (ZK 98.734) which binds to the progesterone receptor and, in turn, inhibits the natural action of progesterone competitively. After the end of treatment on Day 4, various morphological, immunocytochemical, biochemical, and pharmacological analyses were performed. Experimental animals at Day 9 were later used as recipients for blastocyst (Day 4 p.c.) transfers. Antiprogesterone treatment was performed by per os application via a gastric cannula.

4-5 days later and, as soon as epithelial restitution is complete, endometrial protein secretion may commence.

\section{Rabbit pseudopregnancy as a model for the human luteal phase}

The pseudopregnant rabbit has been suggested as a suitable animal model for physiological and endocrinological studies of the human luteal phase (Fischer et al., 1985). Since both ethical and practical reasons restrict direct pharmacological, endocrinological and cell studies in human patients, our basic research was conducted in rabbits. Pseudopregnancy in rabbits is defined by corpus luieum function from Day 1 to Day 12 after injection with human chorionic gonadotrophin (hCG), as demonstrated by peripheral progesterone concentrations and the changes in uterine protein secretion (particularly uteroglobin) (see Fig. 3). Rabbits do not show endometrial desquamation, but demonstrate remarkable regeneration of the progestationally transformed endometrium up to Day 18 of pseudopregnancy.

Under normal conditions in rabbit pregnancy, the preimplantation phase is defined as the period from Day I to Day 7 post coitum (p.c.). Differences between the preimplantation phases of normal early pregnancy and pseudopregnancy are currently the subject of detailed research projects. The various stages of normal early pregnancy and of pseudopregnancy are characterized by a quantitative, rather than a qualitative, shift in the protein pattern of uterine secretion.

After endocrinological studies dealing with classical hormone substitution and experimental induction of hormone imbalances (Beier, 1974; Beier \& Mootz, 1979; Beier et al., 1980; Elger \& Beier, 1982), our present research is on progesterone antagonists used in various protocols to 

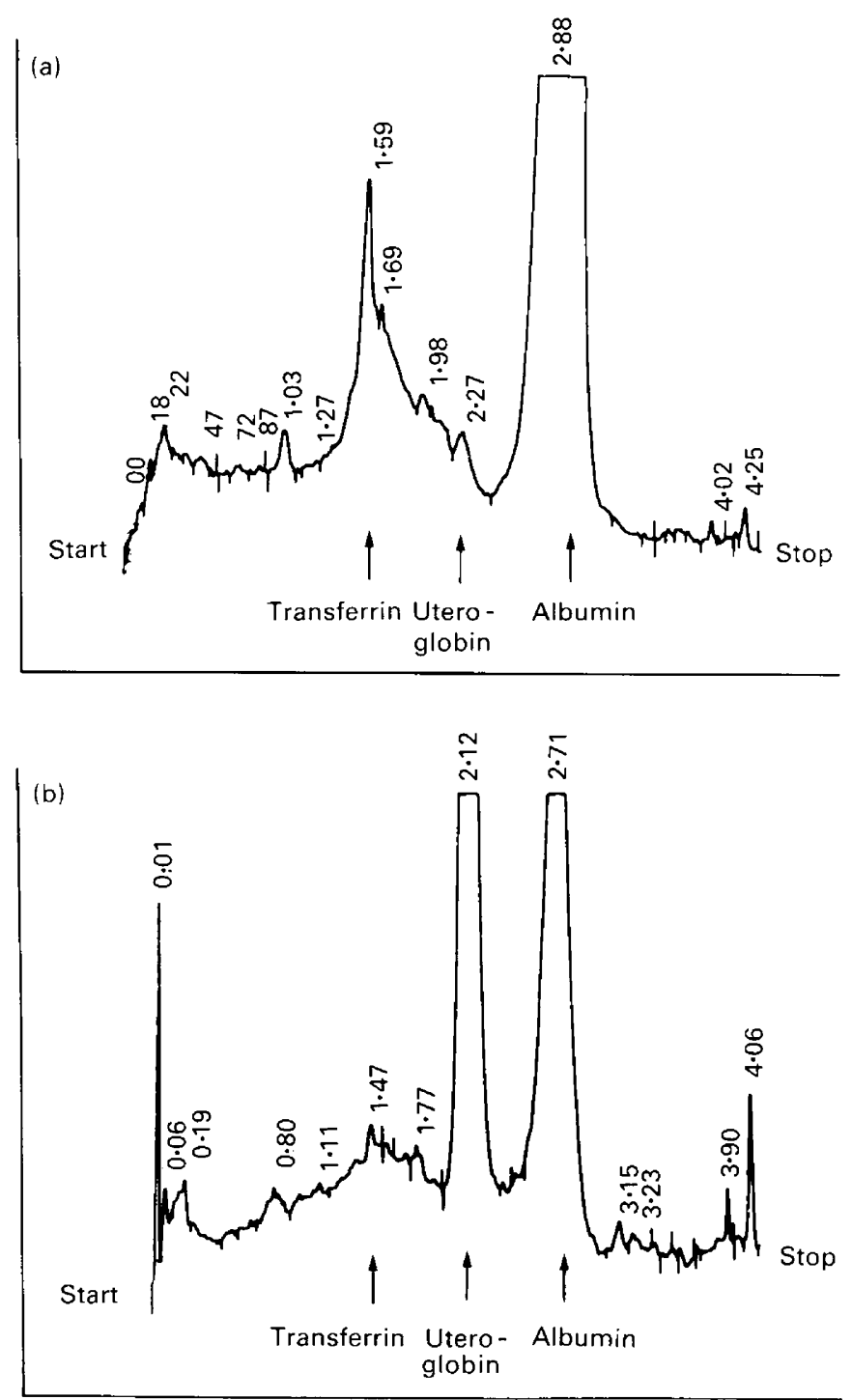

Fig. 5.

elucidate the regulation for the luteal phases, uterine transformation and adaptations which result in a receptive endometrium (Beier et al., 1986; Hegele-Hartung et al., 1986), the prerequisite for implantation. There is by now considerable interest in the process of implantation in humans, because of the high rates of failure of establishing pregnancies after IVF/ET, which seems to be partly due to the condition the endometrium after transfer of the embyro into the uterine cavity (Beier et al., 1983; Beier 1985). Failure of implantation, however, is not just a problem of assisted reproductive therapies, but it occurs with relatively high frequencies in natural early human pregnancies (Short, 1979).

A complete understanding of the mechanism by which 'receptivity' promotes implantation requires the identification and the isolation and purification of large quantities of molecules which are the essential components of the uterine luminal milieu, defined as 'receptive'. Our initial attempts to determine such components in man, performed from 1968 to 1974, described human 

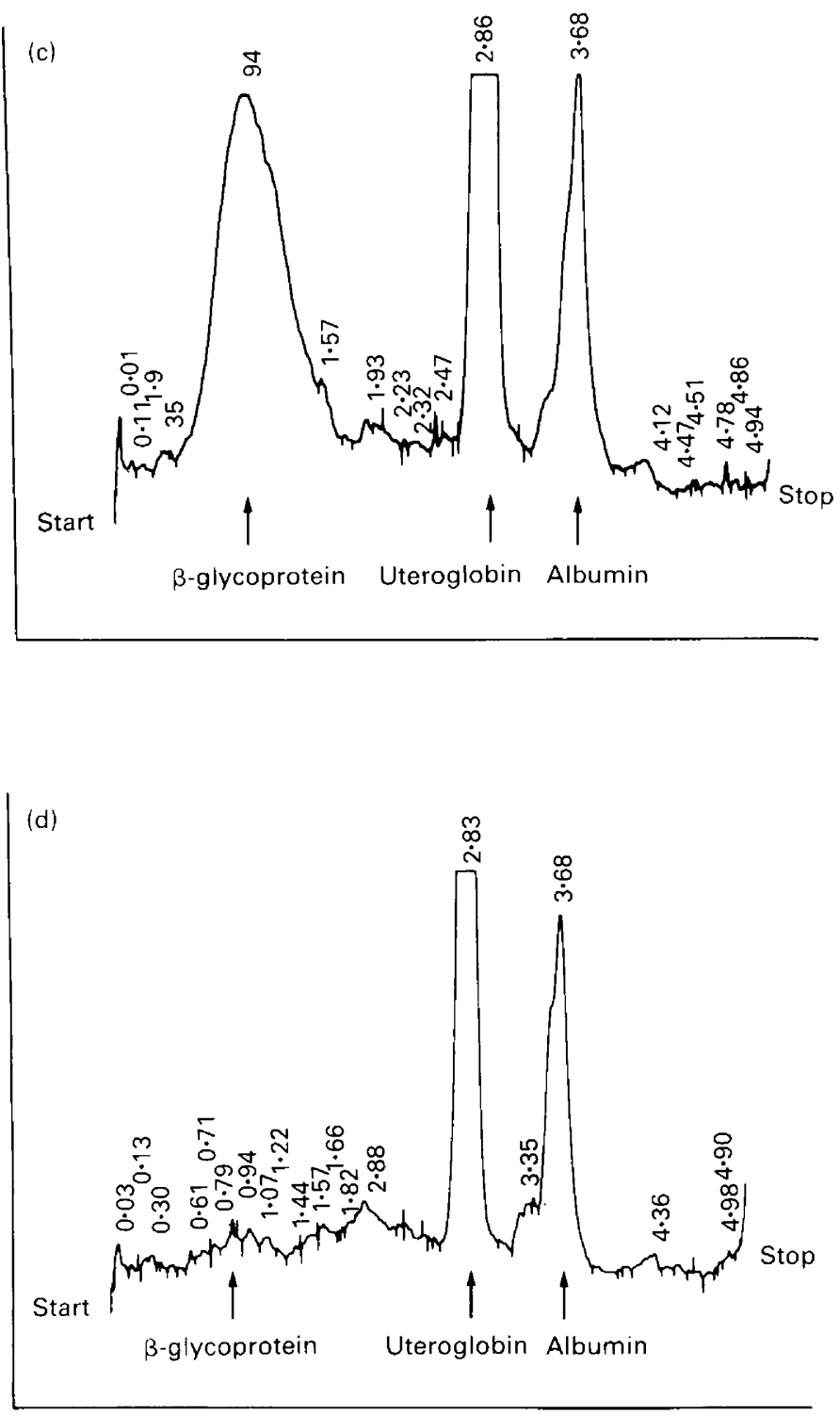

Fig. 5.

Fig. 5. Densitometric analysis of the protein pattern from flushed rabbit uterine secretion at (a) Day 5 of pseudopregnancy after progesterone antagonist treatment at Days 2, 3, 4 (see Fig. 4); release of uteroglobin is significantly inhibited. The pattern of this stage is similar to the normal, untreated stage of Day 1 p.c; (b) Day 8; release of transferrin is significantly reduced, uteroglobin is now released in considerable amounts and albumin percentage is lower. This pattern resembles the normal stage at Day 4 p.c; (c) Day 12; the release of uteroglobin is at a maximum, albumin is further reduced and the large $\beta$-glycoprotein peak appears. This pattern is equivalent to the normal, untreated stage at Day 7 p.c. and shows the 'receptive' protein pattern of the uterine secretion; (d) Day 14; uteroglobin is still released in considerable amounts, but the large $\beta$-glycoprotein peak has disappeared. This pattern is similar to the normal, untreated stage at Days $10-11$ of pseudopregnancy. Electrophoretic separation was performed by a nondenaturating PAA-slab gel system (7.5\% PAA). Coomassie Blue-R-250 staining. Ultro-Scan-XL, He-Ne-Laser $633 \cdot 0 \mathrm{~nm}$. 


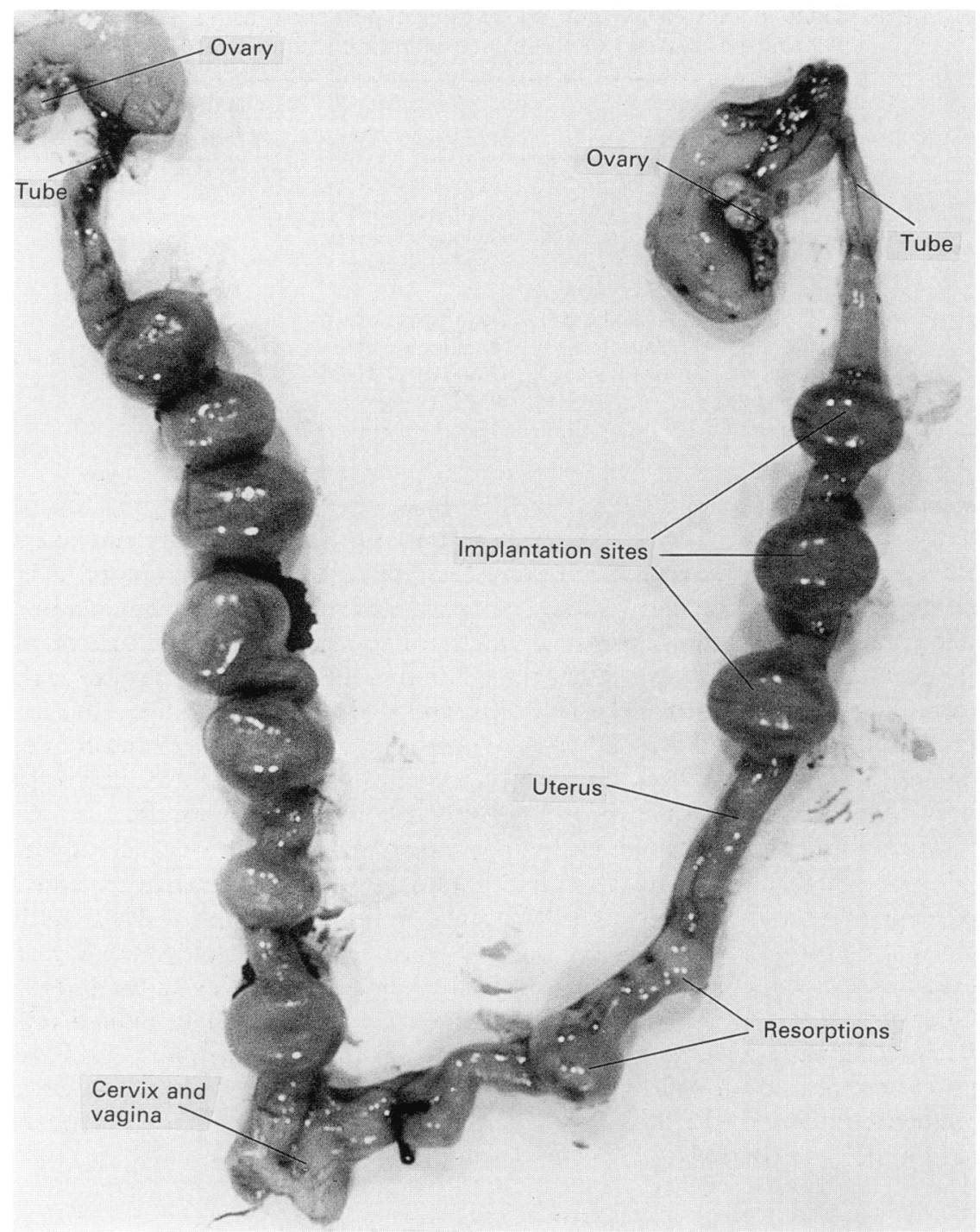

Fig. 6. Genital tract of a pregnant rabbit at Day 16 after initiation of pseudopregnancy and 7 days after embryo transfer of 4-day-old blastocysts. The recipient mother was treated with progesterone antagonists at Days 2,3, and 4 of her pseudopregnancy. Thereafter, at Day 9 of her pseudopregnancy, normal blastocysts from an untreated donor mother (Day 4 p.c.) were transferred. Within the 'delayed secretion' recipient uteri, which had developed a protein pattern of a Day 4 stage of pseudopregnancy, normal implantations and normal embryonic development were achieved.

uterine protein patterns and searched for an equivalent of uteroglobin in human uterine secretion (Beier et al., 1970; Beier \& Beier-Hellwig, 1973; Beier, 1974).

When electrophoretic, chromatographic and biological methods became extremely sensitive, several research groups started working independently on the isolation and identification of single uterine proteins which were immunologically identical to the placental proteins PP12 and PP14. These two proteins were soon characterized as endometrial proteins (Bohn \& Kraus, 1980; Bohn et al., 1982). Since the success of the radioimmunological determination of these endometrial proteins 
Table 1. Results of embryo transfer experiments using "synchronized' blastocysts to delayed-secretion recipient rabbits

\begin{tabular}{llc}
\hline $\begin{array}{l}\text { Treatment for cause } \\
\text { of delayed secretion }\end{array}$ & \multicolumn{1}{c}{$\begin{array}{c}\text { Transfer } \\
\text { constellation }\end{array}$} & $\begin{array}{c}\text { Implantation } \\
\text { rate }(\%)\end{array}$ \\
\hline Oestradiol-17ß post coitum & $\begin{array}{l}\text { Day 4 blastocysts } \\
\text { into Day 8 uteri } \\
\text { Day 4 blastocysts } \\
\text { into Day 4 uteri }\end{array}$ & 62 \\
Controls without treatment & $\begin{array}{l}\text { Day 4 blastocysts } \\
\text { Antiprogesterone (ZK 98.734) }\end{array}$ & 65 \\
$\begin{array}{l}\text { in early preimplantation } \\
\text { Control without treatment }\end{array}$ & $\begin{array}{l}\text { Day 4 blastocysts } \\
\text { into Day 4 uteri }\end{array}$ & 59 \\
\hline
\end{tabular}

within peripheral blood plasma, 'blood tests' have been developed for diagnostic procedures to predict the functional stage of the endometrium, but so far such tests are not reliable, partly because other sources of synthesis and release of these proteins have been identified in man and partly because circumstantial evidence does not support the hypothesis that peripheral blood plasma concentrations accurately reflect substantial synthesis and luminal release of endometrial proteins. The cellular and histological compartmentation of the endometrium suggests that specific secretory proteins are not released at the same time and at the same quantities into the peripheral circulation. On the contrary, all cell biological evidence on the compartmentation of epithelium, stroma, glands and microcirculation points to the conclusion that those specific protein concentrations in the blood plasma are different from their origin in the endometrium.

We are faced with the experimental results and facts from our earlier work (Beier 1982; Beier $e t$ al., 1983) that one single uterine protein alone cannot be used as a marker for receptivity. It was always the whole pattern of electrophoretically separated proteins that provided us with the most reliable information for a diagnosis of the receptive uterus. For better understanding of the comparative evaluation of the equivalent situation in the human uterus during the luteal phase, we compared densitometric protein patterns of 5 compartments involved in human reproduction (Fig. 3). The protein patterns of uterine secretion and oviduct fluid are similar and have common parts that do not appear in the follicular fluid, peritoneal fluid or blood serum. We have evidence that densitometric tracing of the SDS-PAGE samples of uterine secretion will be promising for computerized evaluation (Beier-Hellwig et al., 1988, 1989).

\section{Delayed uterine secretion}

Uterine secretion contributes to synchronization by varying and adapting its protein components. This has been demonstrated in rabbits in our biochemical and endocrinological studies, which resulted in the discovery of the phenomenon of 'delayed secretion' (Beier et al., 1971; Beier, 1974) and was proved in embryo transfer experiments using 'delayed secretion rabbits' as recipient mothers (Beier et al., 1972; Adams, 1973). Synchrony, as a fundamental requirement in mammalian reproduction, had been conclusively demonstrated by Chang (1950) in embryo transfer experiments in rabbits, which had shown that rabbit morulae or blastocysts could only overcome an asynchronous phase of up to 2 days. The more convincing biological proof of the pivotal role of the uterine secretion resulted from our experiments (Beier et al., 1972), in which 4-day-old blastocysts overcame an asynchronous phase of 4 days. We observed normal offspring after normal, 4-day-old blastocysts had been transferred to a recipient mother 8 days post coitum, whose uterine milieu corresponded to a Day-4 uterine protein pattern as a result of an experimentally delayed secretion. This experiment proved that 'receptivity' within the foster mother can be shifted in mammalian reproduction. 


\section{Progesterone antagonist treatment during the preimplantation phase in pseudopregnant rabbits}

Progesterone inhibition studies are now possible using true antagonists which act at target tissue level, competing with the progesterone molecule at its receptor protein. The synthetic steroids Mifepristone (RU 38.486, Roussél-Uclaf, Romainville/France) and Lilopristone (ZK 98.734 Schering, Berlin and Bergkamen/Germany) are potent compounds with antiprogesterone activity (Philibert et al., 1982; Rauch et al., 1985; Elger, 1985; Elger et al., 1986; Henderson, 1987). Measuring the release of uteroglobin, a specific progesterone marker molecule, has proved to be an effective method of determining progesterone antagonist effects.

Adult nulliparous female rabbits (mixed breeds) were treated per os with 2 or $20 \mathrm{mg} \mathrm{BW} \mathrm{ZK}$ $98.734 / \mathrm{kg}$ (in oily solution Myrj) by gastric cannulae on Days 2, 3 and 4 of pseudopregnancy (after hCG). One group of animals received the steroid by s.c. injection, the other (control) group received only the vehicle (see Fig. 4). Uteri were removed after sacrificing the animals at Days 5, 6, $7,8,10,12$ and 14 of pseudopregnancy, flushed with distilled water and subjected to isolation of endometrial tissue for homogenization. After preparation of secretion and endometrial tissue proteins, all samples were examined by PAGE electrophoresis in $7.5 \%$ PAA slab gels and in $12 \cdot 5-25 \cdot 0 \%$ SDS-PAA gradient gels.

The progesterone antagonists Mifepristone and Lilopristone inhibit the synthesis and release of uteroglobin. Within the uterus of treated animals this can be demonstrated convincingly by examination of uterine secretion at Day 5 of pseudopregnancy, which is $24 \mathrm{~h}$ after the end of treatment (Fig. 5). After the subcutaneous application of Lilopristone (ZK 98.734) the complete inhibition of uteroglobin secretion continues as can be shown in animals examined at Days 6, 8 and 10 after hCG injection (corresponding to p.c.). These points of investigation are equivalent to 48 , 96 or $144 \mathrm{~h}$ after the end of treatment with progesterone antagonists.

However, when rabbits are treated via a gastric cannula (per os), $48 \mathrm{~h}$ after the end of progesterone antagonist application, the synthesis and release of uteroglobin obviously start again. This can be demonstrated in protein patterns in uterine flushing and by immunological means. During further time after the end of treatment per os, release of uteroglobin and all other progesteronedependent proteins increases again and attains a normal sequence of protein secretion patterns. This phenomenon of a delayed uterine secretion, by which from Days 8 to 14 after hCG normal preimplantational secretory patterns appear, resembles the patterns from Day 4 up to Day 8 of untreated physiologically normal pseudopregnant rabbits. The densitometric PAA-gel-electrophoretic patterns show this phenomenon clearly, because each pattern that is typical for 1 day before preimplantation reappears about 4 to 5 days later, after progesterone antagonist treatment. The proteins within the patterns are developing in physiological proportions, only their timing by luteal regulation, compared with untreated animals, is delayed (Fig. 5b,c,d).

In these experimental animals, we have investigated progesterone concentrations in peripheral blood plasma. There is no drop or obvious loss of progesterone during or after the progesterone antagonist treatment per os. Mifepristone and Lilopristone do not inhibit progesterone release by the corpus luteum, only the progesterone receptors of the endometrium are bound and, in turn, at the target tissue level during antagonist treatment, progesterone cannot stimulate transformation and secretion.

The crucial experiment to find out whether the delayed uterine secretion following progesterone antagonist treatment comprises a 'biologically normal', though temporally shifted, protein pattern, was the transfer of 'synchronized' embryos. Since the intrauterine macromolecular milieu at Day 12 (see Fig. 5c) resembles the normal Day 7 pattern, and the intrauterine macromolecular milieux of Days 8 and 9 resemble the normal pattern found on Day 4, we transferred normal, 4-day-old blastocysts to Day-9 recipients. This transfer constellation represents a 5-day desynchronization, which under normal circumstances, would never permit implantation and pregnancy. The delayed secretion following progesterone antagonist treatment, however, resembled a 5-day retardation in terms of biological parameters. In this sense, the 4-day-old blastocysts had to be designated as 
'synchronized'. The results of our transfer proved convincingly that our assumptions were correct. Sixty-five percent of all transferred blastocysts implanted and established viable pregnancies (Fig. 6 , Table 1). This implantation rate is identical to that of the controls which were transferred at the same time into untreated recipients $(59 \%)$.

\section{Conclusion}

Progesterone antagonist treatment of rabbits during their early phase of pseudopregnancy inhibits the synthesis and release of uteroglobin for a short period. Synthesis resumes within $48 \mathrm{~h}$ of treatment. This behaviour can be seen in all other preimplantation uterine secretion proteins. Since pseudopregnancy in the rabbit was used as a model for the luteal phase of humans, we conclude that a progesterone antagonist treatment at the beginning of the luteal phase may represent the first step in our attempt to extend or to delay the receptive stage of the luteal phase endometrium to meet all requirements for implantation. Such a treatment, particularly with compounds like Lilopristone, could be promising for improving the adaptation of the endometrium to the more slowly developing in-vitro-cultured and retransferred embryos. IVF/ET-programmes performing with the therapy of human sterility as well as programmes improving reproduction in domestic animals would benefit from such exogenous control of the luteal phase and possible significant increase of implantation rates (Beier \& Elger, 1985).

Realising that the protein patterns of the intrauterine milieu are suitable parameters for the diagnosis of the preimplantation stage of the transformed endometrium is a basic and important step forward. Our experiments have indicated that the appropriate preimplantation endometrial stage, which is reflected by its intrauterine protein secretion, is probably more relevant for an establishing pregnancy than the corpus luteum or any other endocrine organ involved in the control of fertilization and the earliest events in pregnancy. This advance in our knowledge concerning synchrony should give important impulses to further research on early pregnancy, particularly on the molecular biological level of the embryonic-maternal dialogue via embryonic and maternal signals and reactions.

We acknowledge the generous support of our research work by the Deutsche Forschungsgemeinschaft, Bonn/Germany (Grants Be 524/7-9 and He 1667/2-1), and by Schering Aktiengesellschaft, Berlin and Bergkamen/Germany. We thank Ria Becht, Jacques Beckman, Barbara Bonn, Susanne Echterhagen, Sonja Sieprath and PD Dr. med. Karl Sterzik for invaluable and fruitful co-operation.

\section{References}

Adams, C.E. (1973) Asynchronous egg transfer in the rabbit. J. Reprod. Fert. 35, 613-614.

Aitken, R.J. (1977) Changes in protein content of mouse uterine flushings during normal pregnancy and delayed implantation, and after ovariectomy and oestradiol administration. J. Reprod. Fert. 50, $29-36$.

Aitken, R.J. (1982) The control of blastocyst activity. In Proteins and Steroids in Early Pregnancy, pp. 233243. Eds H. M. Beier \& P. Karlson. Springer-Verlag, Berlin.

Aumüller, G., Seitz, J., Heyns, W. \& Kirchner, C. (1985) Ultrastructural localization of uteroglobin immunoreactivity in rabbit lung and endometrium, and rat ventral prostate. Histochemistry 83, 413-417.

Bazer, F.W. \& Roberts, R.M. (1983) Biochemical aspects of conceptus-endometrial interactions. J. exp. Zool. 228, 373-383.
Beier, H.M. (1966) Das Proteinmilieu in Blutserum, Uterus und in den Blastocysten des Kaninchens vor der Nidation. In Biochemie der Morphogenese, Sympos Deutsche Forschungsgemeinschaft, pp. 1-10. Konstanz.

Beier, H.M. (1967) Veränderungen am Proteinmuster des Uterus bei dessen Ernährungsfunktion für die Blastocyste des Kaninchens. Verh. disch Ges Zool. 31, 139-148.

Beier, H.M. (1974) Oviducal and uterine fluids. $J$. Reprod. Ferl. 37, $221-237$.

Beier, H.M. (1982) Uteroglobin and other endometrial proteins: biochemistry and biological significance in beginning pregnancy. In Proteins and Steroids in Early Pregnancy, pp. 39-71. Eds H. M. Beier \& P. Karlson. Springer-Verlag, Berlin.

Beier, H.M. (1985) Extrakorporale Befruchtung und Embryotransfer. Grenzen der Methode: Physiologie 
und Pathologie der Implantation. Arch. Gynecol. 238, $67-71$.

Beier, H.M. \& Beier-Hellwig, K. (1973) Specific secretory protein of the female genital tract. Acta Endocrinol, Suppl. 180, 404-425.

Beier, H.M. \& Elger, W. (1985) Progesterone antagonists for the modulation of endometrial transformation. German patent P $3533175.5 /$ US patent No. 4764513.

Beier, H.M. \& Mootz, U. (1979) Significance of maternal uterine proteins in the establishment of pregnancy. In Maternal Recognition of Pregnancy, Ciba Fdn Symp. 64 NS, pp. 111-140. Excerpta Medica, Amsterdam.

Beier, H.M., Petry, G. \& Kühnel, W. (1970) Endometrial secretion and early mammalian development. In Mammalian Reproduction. Kolloquium der Gesellschaft für Biologische Chemie, Mosbach, vol. 2l, pp. 264 285. Eds H. Gibian \& E. J. Plotz. SpringerVerlag, Berlin.

Beier, H.M., Kühnel, W. \& Petry, G. (197l) Uterine secretion proteins as extrinsic factors in preimplantation development. Adv. Biosci. 6: 165-189.

Beier, H.M., Mootz, U. \& Kühnel, W. (1972) Asynchrone Eitransplantation während der verzögerten Uterussekretion beim Kaninchen. Congress Anim. Reprod. Artific. Insem. vol. 3, pp. 1891-1896, München.

Beier, H.M., Mootz, U., Kühnel, W. \& Elger, W. (1979) Studies on the endocrinologically induced destructions of the uterine epithelium. Fifth Congr. Anat. Europ. p. 28. Argum commun Univ Carolinae Praga, Prague.

Beier, H.M., Mootz, U. \& Fischer, B. (1980) New aspects on the physiology of uteroglobin. In Steroid Induced Uterine Proteins, pp. 47-67. Ed. M. Beato. Elsevier/ North Holland Biomedical Press, Amsterdam.

Beier, H.M., Beier-Hellwig, K. \& Delbos, R. (1983) Hormones and proteins involved in uterine preparation for implantation. In Fertilization of the Human Egg in vitro, Biological Basis and Clinical Application, pp. 307-327. Eds H. M. Beier \& H. R. Lindner. Springer-Verlag, Berlin.

Beier, H.M., Hegele-Hartung, C., Bonn, B. \& Elger, W. (1986) Effect of an antigestagen (ZK 98.734) on uteroglobin synthesis and release in the rabbit endometrium. Acta endocr., Copnh., Suppl. 274, 147-148.

Beier-Hellwig, K., Sterzik, K. \& Beier, H.M. (1988) Zur Rezeptivität des Endometriums: Die Diagnostik der proteinmuster des menschlichen Uterussekretes. Fertilitäı 4, 128-134.

Beier-Hellwig, K., Sterzik, K., Bonn, B. \& Beier, H.M. (1989) Contribution to the physiology and pathology of endometrial receptivity: the determination of protein patterns in human uterine secretions. Human Reprod. 4 Suppl. 115-120.

Bohn, H. \& Kraus, W. (1980) Isolierung und Charakterisierung eines neuen plazentaspezifischen Proteins (PP12). Arch. Gynecol. 229, 279-281.

Bohn, H., Kraus, W. \& Winckler, W. (1982) New soluble placental tissue proteins: their isolation, characterization, localization and quantification. Placenta, Suppl. 4, 67-81.

Chang, M.C. (1950) Development and fate of transferred rabbit ova or blastocysts in relation to the ovulation time of recipients. J. Exp. Zool. 114, 197-216.
Dixon, S.N. \& Gibbons, R.A. (1979) Proteins in the uterine secretions of the cow. J. Reprod. Fert. 56, 119-127.

Elger, W. (1985) Effects of prostaglandins and progesterone antagonists on early pregnancy in guinea pigs, comparison with ovariectomy. In Pregnancy Factors pp. 47-51. Eds F. Ellendorff \& E. Koch. Perinatology Press, Ithaca, NY.

Elger, W. \& Beier, H.M. (1982) Pharmacological aspects of early pregnancy and contraception. In Proteins and Steroids in Early Pregnancy, pp. 311334. Eds H. M. Beier \& P. Karlson. Springer-Verlag, Berlin.

Elger, W., Rhode, B., Kosub, B. \& Fähnrich, M. (1986) Effects of PG-induced luteolysis and antigestagens (AG) on early pregnancy in guinea pigs. Acta endocr., Copnh., Suppl. 274, 13.

Fischer, B., Winterhager, E., Busch, L.C. \& Beier, H.M. (1985) Die Pseudogravidität des Kaninchens als reproduktionsbiologisches Modell. Fertilität 1, 101109

Fishel, S.B. (1980) Radiolabelled uterine proteins during early pregnancy and pseudopregnancy in mice after unilateral ovariectomy and superovulation. $J$. Reprod. Fert. 59, 473-478.

Hegele-Hartung, C. \& Beier, H.M. (1985) Immunocytochemical localization of uteroglobin in the rabbit endometrium. Anat. Embryol 172, 295-301.

Hegele-Hartung, C., Bujotzek, G. \& Beier, H.M. (1986) Effect of an antigestagen (ZK 98.734) on uteroglobin localization in the rabbit endometrium: an immunocytochemical study. Acta endocr., Copnh., Suppl. 274, 169.

Henderson, D. (1987) Antiprogestational and antiglucocorticoid activities of some novel $11 \beta$-aryl substituted steroids. In Pharmacology and Clinical Uses of Inhibitors of Hormone Secretion and Action, pp. 184-211. Eds B. J. A. Furr \& A. E. Wakeling. Ballière Tindall, London.

Laster, D.B. (1977) A pregnancy-specific protein in the bovine uterus. Biol. Reprod. 16, 682-690.

Loosfelt H., Fridlandsky, F., Savouret, J.F., Atger, M. \& Milgrom E. (1981) Mechanism of action of progesterone in the rabbit endometrium. $J$. Biol. Chem. 256, 3465-3470.

Mulholland J. \& Villee C.A. Jr (1984) Proteins synthesized by the rat endometrium during early pregnancy. J. Reprod. Fert. 72, 395-400.

Philibert, D., Deraedt, R., Tournemine, C., Mary, I. \& Teutsch, G. (1982) A potent antiprogesterone. $J$. Steroid Biochem. 17, 204.

Pratt, H.P.M. (1977) Uterine proteins and the activation of embryos from mice during delayed implantation. J. Reprod. Fert. 50, l-8.

Rauch, M., Loosfelt, H., Philibert, D. \& Milgrom, E. (1985) Mechanism of action of an antiprogesterone, RU 486, in the rabbit endometrium: effects on the uteroglobin gene. Eur. J. Biochem. 148, $213-218$.

Roberts, G.P. \& Parker, J.M. (1974) Macromolecular components of the luminal fluid from the bovine uterus. J. Reprod. Fert. 40, 291-303.

Roberts, G.P., Parker, J.M. \& Symonds, H.W. (1976) Macromolecular components of genital tract fluids from the sheep. J. Reprod. Fert. 48, 99-107. 
Roberts, R.M. \& Bazer, F.W. (1980) The properties, function and hormonal control of synthesis of uteroferrin, the purple protein of the pig uterus. In Steroid Induced Uterine Proteins, pp. 133-149. Ed. H. Beato. Elsevier/North-Holland Biomedical Press, Amsterdam.

Short, R.V. (1979) When a conception fails to become a pregnancy. In Maternal Recognition of Pregnancy, Ciba Found Sympos 64 NS, pp. 377-387. Excerpta Medica, Amsterdam.

Shroyer, K.R., William, C.L., Miller, G.J. \& Gerschenson, L.E. (1987) Uteroglobin production in the pseudopregnant rabbit uterus. Immunohistochemical studies. Histochemistry 87, 471-478.

Squire, G.D., Bazer, F.W. \& Murray, F.A. (1972) Electrophoretic proteins of porcine uterine protein secretions during the estrous cycle. Biol. Reprod. 7, $32 \mathrm{I}-325$.

Surani, M.A.H. (1972) Cellular and molecular approaches to blastocyst uterine interactions at im- plantation. In Development in Mammals, vol. 1, pp. 245-305. Ed. M. H. Johnson. North Holland, Amsterdam.

Surani, M.A.H. (1976) Uterine proteins at the time of implantation in rats. J. Reprod. Fert. 48, 141-145.

Suske, G., Wenz, M., Cato, A.C.G. \& Beato, M. (1983) The uteroglobin gene region: hormonal regulation, repetitive elements and complete nucleotide sequence of the gene. Nucleic Acids Res. 11, 2257-2271.

Warembourg, M., Tranchant, O., Atger, M. \& Milgrom, E. (1986) Uteroglobin messenger ribonucleic acid: localization in rabbit uterus and lung by in situ hybridization. Endocrinology 119, 1632-1640.

Zavy, M.T., Sharp, D.C., Bazer, F.W., Fazlabas, A., Sessions, F. \& Roberts, R.M. (1982) Identification of stage-specific and hormonally induced polypeptides in the uterine protein secretions of the mare during the oestrous cycle and pregnancy. J. Reprod. Fert. 64, 199-207. 